\title{
The Politics of 'Dolphin-Safe' Tuna in the United States: Policy Change and Reversal, Lock-in and Adjustment to International Constraints (1984-2017)
}

\author{
RODRIGO FAGUNDES CEZAR * \\ Graduate Institute of International and Development Studies, Switzerland
}

\begin{abstract}
Recently, the World Trade Organization (WTO) granted Mexico the right to retaliate against the US as a compensation for losses related to the US 'dolphin-safe' label (May 2017). Despite the diversity of works on the issue, few analyze the changes in the US approach to dolphin protection as a result of international and domestic pressures related to the tuna-dolphin controversy. This paper seeks to understand such changes and their consequences using the process tracing method. It shows that (1) the US approach to dolphin protection passed through a process of policy change motivated by trade and diplomatic concerns mediating dolphin protection, and that (2) it was partially reversed in court as an outcome of the concessions offered to get the policy change approved. Finally, the paper argues that (3) this process led to the lock-in of the US 'dolphin-safe' label and to its expansion in response to recent WTO decisions.
\end{abstract}

\section{Introduction}

The tuna-dolphin issue has received considerable attention over the years, triggering relevant legal debates ${ }^{1}$ and discussions about the limits of the connection between trade and environmental protection. The issue is now once more in the spotlight after the World Trade Organization's (WTO) decision (May 2017) to grant Mexico the right to retaliate against the US as compensation for losses associated with the US 'dolphin-safe' label - an eco-labeling scheme to inform consumers about how tuna was fished. The objective of this work is to explain the changes in the US 'dolphin-safe' standard and their consequences.

Between 1972 and 1991, the US developed a strong 'dolphin-safe' standard, including sanctions and a rigorous 'dolphin-safe' label. Although such a label was

\footnotetext{
*Email: rodrigo.fagundes@graduateinstitute.ch

Earlier versions of this study benefited from comments and suggestions by James Hollway and Camilla Geraldello. I also thank the two anonymous reviewers and the WTR's Editor for their insightful comments along the peer-reviewing process.

1 See, for instance, Crowley and Howse (2014).
} 
not per se responsible for barring imports, it offered information to consumers, not willing to buy 'unsafe' tuna. However, fishing nations and domestic tuna boat owners were negatively affected by some of these stringent regulations. The connection between domestic and international constraints led to a change in the US stance towards dolphin protection. A policy change followed a 1991 General Agreement on Trade and Tariffs (GATT) ruling that was detrimental to the US, and culminated in the International Dolphin Conservation Program Act of 1997 (IDCPA), a 'softer' compromise towards dolphin protection. This change lifted embargoes against non-'dolphin-safe' tuna imports from Mexico and other fishing nations. It should also have resulted in tuna harvested by setting nets on dolphins to be eligible to receive the 'dolphin-safe' label, as long as no dolphin was killed.

However, the policy change was reversed via legal action, and, in spite of the US government's attempts, the IDCPA was not fully implemented. Furthermore, after 2004 , legislative action in favor of a more lenient 'dolphin-safe' standard was significantly reduced. In view of a WTO complaint filed by Mexico, the Obama Government had to take action to avoid retaliation, but this time the US decided to take a highest common denominator position to dolphin protection, expanding the label requirements to all oceans, as opposed to the initial locus of dispute, the eastern tropical Pacific Ocean (ETP). This decision is puzzling, given that the Obama administration did not take a similar stance in favor of other certifications, such as the Country of Origin Label (COOL), and shows how labels, as transmission belts of consumers' ethical concerns, may have important trade policy consequences at an international level. It is also puzzling that the legislative action in favor of a more lenient US 'dolphin-safe' standard reduced significantly after 2004, while the discussion was pungent during the 1990s. Finally, it is interesting to observe that this is a case in which the policy change reversal was driven by a process of judicial review, which is not usually a veto point in the policy process.

Despite the diversity of the literature approaching the tuna-dolphin issue from a political standpoint, no work to date solves those puzzles either because they are outdated or lack elements to analyze the changes in the US approach to dolphin protection. Among the most pertinent works, Joseph (1994) and Cullet and Kameri-Mbote (1996) have shown interest in analyzing the political and ecosystemic impacts of 'dolphin-safe' standards. In analyzing environmental protectionism, Korber (1998) shows how the US 'dolphin-safe' label generated private gains to the US tuna industry. With focus on the role of NGOs, Wright (2000) discusses the role of the coalition formed by Greenpeace in supporting a change in the US 'dolphinsafe' standard, and Baird and Quastel (2011) show how the NGO Earth Island Institute (EII) assumed a position of leadership in the formulation of a 'dolphinsafe' standard. Except for Bonanno and Constance (2010), the existing literature has not paid systematic attention to the US decision-making process.

Centering my analysis on the connection between domestic and international constraints, this paper seeks to answer the following questions: 'why did a policy change in the US 'dolphin-safe' standard take place?'; 'why was it partially 
reversed?'; and 'what are the consequences of this partial reversal?'. I claim that the change was the result of domestic and international pressures mediated by the US Executive, that it was reversed as a result of the very concessions offered to get it approved in the first place, and that the main outcome of the policy reversal was the lock-in of the US 'dolphin-safe' label. In answering the questions above, this study can complement works on sustainability certification by drawing a clear connection between trade and sustainability standards and fleshing out how domestic political conflicts can affect the internationalization and institutionalization of eco-labels. It also shows how WTO decisions can potentially lead to an increase in dolphin protection, as well as present the puzzling possibility of judicial review becoming a veto point.

This research covers the period between 1984 (date of an amendment that expanded the international reach of US' dolphin conservation laws) and May 2017 (WTO's decision to allow Mexico to retaliate against the US), and resorts to the process tracing method. Process tracing can be summarily defined as a method 'to generate and analyze data on the causal mechanisms, or processes, events, actions, expectations, and other intervening variables, that link putative causes to observed effects' (Bennett and George, 1997: 5). Besides this introduction, this paper presents as follows: (1) the analytical framework and causal claim; (2) a section about the antecedents of the GATT case involving the US and Mexico; (3) a section about the policy change process that culminated in the IDCPA; $(4)$ the partial court reversal of the policy change in the US 'dolphin-safe' standard; and (5) the most recent developments and the WTO case involving the US and Mexico; (6) conclusions.

\section{Analytical framework and causal claim}

\subsection{Public salience and mobilization}

One of the puzzling aspects regarding the tuna-dolphin issue in view of classical collective action literature (Olson, 1977) is the efficiency of NGOs and civil society organizations in pushing for a dolphin protection agenda, given the common idea that diffuse interests, such as NGOs, would find it difficult to mobilize owing to problems of free-riding. To account for this outcome, the baseline of this work is the affirmation that the tuna-dolphin issue had achieved high public salience until the beginning of the 1990s, which is a reasonable affirmation in view of the evidence offered by the existing literature (Destler and Balint, 1999; Baird and Quastel, 2011; Bonnano and Constance, 2010). With that in mind, it is possible to resort to Rasmussen et al. (2014) and note that public salient issues have effects on mobilization of interest groups, since these groups operate as transmission belts between public opinion and policymaking. Another perspective is the one present in Johnson and Prakash (2006), who claim that NGOs should be seen as collective endeavors, and that the division between NGOs, advocacy groups, and social movements is 
being blurred. By modeling NGOs as firms, they show that elements from the heterogenous firm literature, namely differentiation in products and processes, may be relevant to understanding how NGOs overcome their collective action problems.

In view of that, it is possible to analyze the connection between consumer preferences, the mobilization of NGOs, and the political salience of dolphin protection in the US Congress. Baird and Quastel (2011), for instance, highlight the relevance of the EII in pushing for a dolphin protection agenda. Taking into consideration the perspectives of collective action pointed out above, the main elements to understanding the mobilization of the EII are: (1) the salience of the tuna-dolphin discussion, supported by the idea of dolphins as part of a 'charismatic super fauna'; (2) the specificity of the 'dolphin-safe' issue in the strategy of the EII, which may have increased its costs of non-participation in the policy process. Even without the transmission belt of NGOs, the literature on issue salience has shown that the public seeks more information about salient subjects (Hutchings, 2001). That raises attentiveness towards the actions of the congressional representative, whose main individualist objective is to seek reelection.

These elements allow one to analyze (1) the responsiveness of Congress in a moment of high public salience of environmental protection; and (2) mobilization of groups with stakes in the tuna-dolphin issue and their effectiveness in holding the attention of Congress.

\subsection{The role of the US Executive}

The US Executive is subject to different constraints in relation to the US Legislative as (1) it is more politically insulated relatively to Congress; and (2) it is the actor working at the boundary between the international and domestic levels (Putnam, 1988; Conceição-Heldt, 2013). Also, the Executive is not a neutral actor, but has its own ideologies and beliefs. As such, although classic two-level games literature (Putnam, 1988) assumes that the preferences of the negotiator are aligned with that of his/ her domestic constituency, public policy frameworks make it clear that Executive actors are themselves part of advocacy coalitions (Sabatier and Weible, 2007).

In trade or trade-related issues, the US Executive, including the US president (Karol, 2000), on average takes a pro-trade stance. Goldstein (1986), for instance, considers that the US bureaucracy has a bias towards liberalization that finds its roots in US trade policy institutionalization, in spite of some agencies being, on average, more free-trade oriented-Department of Treasury-than others-Department of Labor-for instance. In particular, the Department of State is hesitant to put US trade and diplomatic relations with foreign countries at risk unless necessary to advance a foreign policy goal (Destler, 2005). The US President, in turn, is both influenced by (1) the characteristics of the role, namely, larger constituency and broader concerns linking domestic and international arenas; and (2) by rooted foreign policy ideas of liberal 
internationalism. ${ }^{2}$ In view of that, it is plausible to expect the Executive to mediate environmental concerns with trade and foreign policy calculations when those have commercial and/or political implications to the relation with partner governments.

As posited by the two-level games literature, the negotiator (US Executive) is constrained by events at the domestic and international levels, but also has the strategic advantage of using developments at one level as a tool to create room for maneuvering at the other (Putnam, 1988; Conceição-Heldt, 2013). In addition, as presented by Mo (1994) and Iida (1993), foreign countries exert pressure on the Executive of the nation they negotiate with to have their own preferences met, but, given uncertainty, they may also decide to make concessions so as to reach an agreement. Most times, neither party at the negotiation table is willing to see the other party defect, by virtue of the costs entailed. Given that neither party knows exactly the extent to which the other is able to forge a winning coalition domestically, they are likely to offer concessions, send positive signals, and tone down threats to assure defection is avoided. This means that, in pushing for trade and diplomatic objectives, the Executive has a crucial resource in its favor by being at the domestic-international frontier.

In sum, as an ideological player, the US Executive will try to push for its own trade preferences by teaming up with actors in Congress and in civil society sharing the same views and beliefs (Sabatier and Weible, 2007). Whenever Congress and civil society are mobilized and lean towards a distinct position, external events may serve as a resource for the Executive to sway these opponents. The process is not straightforward and requires concessions and bargaining for a representative to go against the trade preferences of his/her party's leadership, for instance. In the case of the tuna-dolphin issue, I expect Republicans to be more likely to support trade-related initiatives, as evidence shows that they have systematically advocated in favor of free trade in the post-World War II period (Epstein and O'Halloran, 1996), along with the moderate Democrats, given their lower degree of hesitation towards trade liberalization (Hale, 1995).

\subsection{The preferences of interest groups}

The main for-profit groups involved in the tuna-dolphin discussion are canners and fishermen, but they do not necessarily share the same preferences. How do these interest groups position themselves on the tuna-dolphin issue? From an economic perspective, in the same way that free trade may put domestic import-competing producers at a competitive disadvantage regarding foreign products, agents who have to adapt to regulations may face a similar effect in relation to products with lower regulations. In that regard, I suspect that the position of interest groups in the tuna-dolphin discussion is aligned with their dependency on the

2 In that regard, the Trump administration may be an 'outlying case', although it is not yet possible to engage in a full analysis of his trade policy actions. 
ETP region. The ETP has been subject to specific sets of regulations during most of the controversy in view of the association between dolphins and tuna.

I posit that for ETP-dependent groups (small tuna boats unable to travel far away from the US coast), it would be ideal to have stringent regulations applied to foreign competitors as this would serve to protect their rents. If that is feasible, they are likely to align with actors who have a trade-restrictive stance. These groups are also likely to oppose regulations focused solely on the ETP, as this would dilute their competitive position vis-à-vis competitors fishing in other oceans. If it is not feasible to protect their rents by imposing burdens solely on competitors, these actors are likely to support a solution (multilateral agreements, for instance) that puts foreign and domestic groups on the same footing to avoid regulatory advantage. In turn, ETP-independent groups, or ones that can easily move out of the ETP region (tuna canneries which can relocate or which have branches in other regions), do not have incentives to oppose restrictive measures centered on the ETP, since the costs of non-participation are low. However, they may be opposed to regulations that address the tuna industry in general, given that they compete against other fish and non-fish products.

\subsection{Judicial review and 'allies in the judiciary'}

After approval of a policy, its implementation is of similar relevance. During the implementation of a law, judicial review of an agency's ruling can be used as a means of political control (1) by imposing a particular sequence of events on agency decision-making and creating an 'early warning'; (2) by affording time for politicians to intervene; and (3) by 'stacking the deck' in favor of certain constituencies (McCubbins et al., 1987). In that regard, the US Administrative Procedures Act (APA) has been established to offer clear guidelines for judicial review of agencies' actions. From the perspective of the congressional dominance literature, the judicial review of bureaucratic actions is an extension of congressional intent. However, works have shown that the outcome of lawsuits is not disconnected from the court that judges the case (Sheehan, 1990; Humphries and Songer, 1999; Sustein et al., 2006). Indeed, some works consider the Ninth Circuit Court of Appeals - responsible for judging many of the cases raised by the EII during the tuna-dolphin issue - the NGOs' 'ally in the judiciary' (Bonanno and Constance, 2010), and, thus, an important resource available to advocates of dolphin protection.

In the case of procedural control, an ideological explanation may not suffice to account for a policy change reversal, given that decisions are related to the implementation of a public policy that has already been approved. Even though constitutional courts may become veto players in some circumstances (Volcansek, 2001), only in exceptional cases can judicial review play the same role. I argue that the US 'dolphin-safe' standard is one of such cases, because the very provisions of the legislation introducing the policy change opened the possibility for judicial review to become a veto point. 


\subsection{Lock-in and the power of certifications}

On the basis of the elements I pointed out above, the main causal mechanism of this paper is the following: against the background of an attentive public and mobilized NGOs willing to push for strict dolphin protection (1) the US administration pushed for a perspective of environmental protection mediated by international trade and diplomatic concerns and, as such, (2) played a pivotal role in forming a coalition in Congress to change the US 'dolphin-safe' standard by aligning with actors with close preferences, as well as by using international pressures to push for changes; (3) the US administration and its allies (Republicans and tuna boat owners) had to offer concessions to opponents in order to form a winning coalition; (4) concessions were such that the administration was forced to provide scientific support that could not be found, triggering (5) a judicial review of administrative procedures that ultimately allowed a partial reversal of the policy change.

In that context, the partial policy change reversal also resulted in a consistent change in the beliefs of the Executive and its congressional allies regarding the prospects of the political strategies and policy instruments used in the tuna-dolphin case. ${ }^{3}$ It derived from (1) the jurisprudence created after successive judicial decisions; and (2) the absence of the scientific knowledge upon which the implementation of the IDCPA was made contingent. It led to a lock-in of the 'dolphin-safe' label, which affected the US position vis-à-vis the WTO's disputes. The lockingin also served as a disincentive to new policy change attempts. Obviously, this outcome was not initially predicted by the IDCPA, but still was a direct result of it, and thus can be considered an unintended consequence (Fioretos, 2011) of the US Executive's strategy to change the US 'dolphin-safe' standard.

Using this causal mechanism, I expect to contribute to the literature on sustainability certifications. As a transmission belt linking consumers' ethical concerns, cultural traits, and market choices (Rainforest-Alliance, 2012), studies show that eco-labels have an impact on consumer behavior (Teisl et al., 2002). In the case of 'dolphin-safe' tuna, this change in consumer behavior resulted in a de facto trade barrier that led the WTO to calculate a level of impairment of US\$163.23 million per year in the case of Mexico. The literature also shows how sustainability certifications affect forms of governance (De Vos and Bush, 2011), represent new territorialities (Vandergeest et al., 2015; Vandergeest and Unno, 2012), as well as new forms of social contract (Giovannucci and Ponte, 2005). Complementing these works, the causal claim of this research is relevant to an understanding of the process by which domestic and international constraints lead certifications to impact trade politics, even if, in this instance, these labels do not per se prohibit the import of tuna from other countries.

3 See May (1992) for a categorization of the distinct types of policy and political learning. 


\section{Tracing the tuna-dolphin issue}

Having sketched the main analytical elements that underlie this analysis of the US 'dolphin-safe' standard, I now proceed to the process tracing of the events stretching from 1984 to 2017. This section is divided into four subsections, (1) the escalation of the tuna-dolphin issue and GATT findings, (2) the process leading to the IDCPA, (3) IDCPA's judicial repercussions, and (4) the recent developments of the WTO controversy.

\subsection{Antecedents: an assertive Congress, a more lenient Executive, and Mexico's complaint (1984-1991)}

The eastern tropical Pacific Ocean (ETP) is an area covering more than 18.1 million $\mathrm{km}^{2}$ from southern California to Chile. For motives unknown, in the ETP schools of yellowfin tuna associate with dolphins - this does not usually happen in other parts of the world, such as the Western Pacific and Indian Oceans. Due to that association, fishermen encircle and set nets on dolphins, knowing that underneath the surface tuna would follow the movements of those air-breathing mammals. In the process, dolphins end up being trapped in the nets and drowned, suffering injuries or experiencing high levels of stress. Deaths amount to more than 6 million since the 1950s (Marine Mammal Commission, 1996). Based on the public outcry that followed the massive incidental killing of dolphins in the 1950s and 1960s, the US Congress enacted the Marine Mammal Protection Act of 1972 (MMPA).

The MMPA prohibits, with certain exceptions, the 'take' of marine mammals in US waters and by US citizens on the high seas. 'Take' is defined, according to the National Oceanic and Atmospheric Administration (NOAA) as 'to harass, hunt, capture, collect, or kill, or attempt to harass, hunt, capture, collect, or kill any marine mammal' (NOAA, 2016). Initially, however, MMPA requirements applied only to the US vessels, leaving US tuna boat owners and fishermen at a competitive disadvantage in relation to foreign vessels (Korber, 1998; Bonanno and Constance, 2010). Following public and private pressure, in 1984 the US Congress passed amendments to the MMPA, specifying that tuna caught using purse-seine nets could only be imported if it was documented that (1) the exporter implemented a dolphin protection program 'comparable' to that of the United States, and (2) the average incidental dolphin kill rate was 'comparable' to that of the US fleet (Trachtman, 1992, cited in Bonanno and Constance, 2010). The National Marine Fisheries Service (NMFS), a division of the Department of Commerce's NOAA responsible for marine stewardship, threatened to ban tuna imports from Latin American countries if they did not reduce their killing of dolphins, but have not been diligent in applying the law, according to environmental groups (Shabecoff, 1988).

Senator John Kerry (D-CO) considered that the Department of Commerce and the Department of State had demonstrated 'malaise' in addressing the issue, to 
which the NMFS responded by stressing its complex nature (Shabecoff, 1988). In 1988, a new amendment was approved to deal with the 'foreign fleet issue'. As pointed out by Senator Breaux (D-LA) during the hearing on the reauthorization of the MMPA (4 April 1988), 'the program is working in the United States. The problem is not with our tuna industry. The problem is with the foreign fishermen, who take four times more porpoises than our industry does.' The dolphin issue gained more attention after a 1988 footage made by biologist Samuel LaBudde, showing the Panamanian vessel Maria Louisa setting nets on dolphins and killing many in the process. The footage triggered boycotts against the tuna industry that gave more salience to the discussion. Restaurants boycotted tuna by taking it off their menus, and even the city commissioners of St. Petersburg Beach did the same and urged residents to follow suit (Curtin and Eastman, 1989).

However, enforcement of the 1988 amendment was again considered deficient. The Department of Commerce stated in 1988 that the new rules would be implemented after the amendment, but that they would take three years to take effect. According to Senator John Breaux (D-LA), a 'final interim' rule took so long to be issued by the NMFS because of concerns that moving too fast and too abruptly against foreign nations might push them to seek alternative markets for their tuna. The fear was that 'the companies could forget about the US and fish with impunity on the dolphins', as said by a congressional representative (Weisskopf, 1988: 1). In a hearing, Charles Furlleton, then director of the NMFS, said that 'it's a very delicate operation to get those regulations. We developed some over a year ago, which were not acceptable to either the tuna industry or the foreign nations' (Brower, 1989, cited in Bonanno and Constance, 2010: 61). As expected, the administration took into consideration both domestic and international constraints and was concerned about repercussions in terms of its relation to third countries.

In February 1989, the Ninth Circuit Court of Appeals required that US tuna vessels in the ETP had a certified observer. In addition, a judicial decision ordered the application of import bans on countries that did not show comparability as required by the MMPA amendments. The Secretary of Commerce and the Secretary of Treasury defended themselves by mentioning the complex nature of the calculations and the time constraints. In 1992, the Ninth Circuit again ruled in favor of the EII when addressing the embargo to intermediary nations, the socalled 'secondary embargo'. 4 The 1984 and 1988 amendments were supported by the US tuna industry, which opposed the approval of the MMPA in 1972 (DeSombre, 2000). These groups, not able to revert the MMPA, found in the enforceability of US rules to foreign countries a reasonable solution to a growing loss of competitiveness in face of foreign fleets. For instance, the American Tuna Foundation strongly advocated in favor of import regulations in Congress 
hearings: 'The US tuna industry believes that the import regulations of March 18, 1988 were long overdue' (Burney, 1988: 115). Congress, along with the initial idea of using market access to enhance protection to dolphins, also corroborated the idea of shielding the US tuna industry from 'environmental dumping'. For environmental NGOs, on the other hand, that would be the opportunity for more stringent rules on dolphin protection.

However, fishermen and tuna boat owners were not satisfied with the need to have observers onboard US vessels in the ETP, given the costs of adapting to the regulation. The government and the tuna industry considered that the addition of observers would hurt trade while few dolphins would be saved (New York Times, 1989). When, in 1989, Barbara Boxer (D-CA) proposed the creation of a legislation to establish a 'dolphin-safe' label for tuna products, both the Bush Administration and the US tuna industry opposed it (Bonanno and Constance, 2010). They considered that it would reduce tuna stock by forcing the harvesting of young fishes, also arguing that the legislation would threaten the US tuna fleet and be difficult to enforce (Meinert, 1989). At this point, it was already possible to note, as expected, that the US tuna fleet was in favor of comparability measures that would put them on an equal footing with foreign vessels, but not in favor of regulations only applicable to the ETP region.

The level of public salience of the tuna-dolphin issue, which was already high, reached a completely new level after the Panamanian vessel footage. With the amendments to the MMPA and consumer boycotts, the mood of Congress was favorable to the adoption of even more strict measures for the protection of dolphins. Congress had been attracted by the appeal of the 'charismatic megafauna' campaign launched by NGOs such as the EII, which offered a simple and effective message to the US public. The EII launched a campaign for ethical tuna fishing and in 1990 created a 'dolphin-safe' label that would only be granted to tuna that was not caught by encircling dolphins. The NGO, by means of its International Marine Mammal Project (IMMP), focused on reducing the killing of dolphins to zero. In April 1990, as a result of the consumer boycotts, the three largest sellers of canned tuna in the US - StarKist, Chicken of the Sea, and Bumble Bee-announced they would stop buying tuna caught in nets that also encircled dolphins (Baird and Quastel, 2011).

The EII's level of mobilization was high and Congress, particularly the Democrats, felt the attention given by US consumers to the tuna-dolphin issue. In that context, the EII consumer campaign was particularly successful and contributed to the approval of the Dolphin Consumer Protection and Information Act (DCPIA) in the fall of 1990, largely reflecting its concerns (Baird and Quastel, 2011) and the ethical concerns of the American public. The DPCIA prohibited producers, importers, exporters, distributers, or sellers from labeling as dolphin-safe any tuna product from the ETP unless it was certified that the boats did not set nets on dolphins. Less well known, although equally important, is the fact that the DCPIA did not allow tuna from any part of the globe to be 
labeled 'dolphin-safe' if the boat used driftnets. The issue of driftnets has become a top priority among NGOs, including the EII, and reached considerable political salience in the 1980s. In 1989, the United Nations General Assembly approved Resolution 44/225 demanding that 'immediate action should be taken to reduce progressively large-scale pelagic driftnet fishing activities' (UNGA, 1989), considering, furthermore, that the practice should cease to exist by 30 June 1992 . The DCPIA did not per se bar the imports of tuna, simply creating a labeling scheme. Nevertheless, works show that the 'dolphin-safe' label did affect consumer behavior (Teisl et al., 2002), and, in this case, became a de facto barrier against non'dolphin-safe' tuna caught in the ETP region.

The DPCIA resulted in a significant decline in the mortality of dolphins in the ETP and contributed to reducing large-scale drift-netting in the Western Pacific and Indian Oceans (Baird and Quastel, 2011). This evidences that the DPCIA was not focused on Latin American countries only, contrary to what would be expected by those who considered the law an act of environmental protectionism. The driftnet discussion is much bigger than its connection with the tuna industry, and its undebatable environmental impact amplified international and US domestic opposition against its use. The use of purse-seine nets and the technique of encircling dolphins, in turn, generated debates on whether these methods were more harmful to the ecosystem than others, and became the symbol of the tunadolphin controversy.

The acceptance of the 'dolphin-safe' label by big tuna canneries is associated with their relocation to Asian countries (Korber, 1998). In the beginning of the 1990s, cheap tuna could be bought from other areas of the world, where tuna did not usually associate with dolphin, particularly the Western Pacific and Indian Oceans, and could quickly be transported to big canneries installed in Thailand, which packed and then exported the tuna to the US (Baird and Quastel, 2011: 341). As such, it was much easier for canneries to avoid the heavily regulated ETP region. These operators would have been affected by the DCPIA's provision on driftnets, but had already compromised to not use such a method given the pressures from consumers. August Felando, president of the American Tunaboat Association, called the decision to buy 'dolphin-safe' tuna a 'market ploy' to increase tuna sales. The US tuna industry differed from tuna canners in that it was very concerned with the labeling requirements, and considered that the measures would negatively impact the US tuna fleet (Shabecoff, 1990). In parallel to this economic aspect, expected by the framework, tuna boat owners also displayed ecosystemic concerns related to the bycatch of juvenile tuna.

Mexico, one of the main countries affected by the embargoes raised by the United States and by the 'dolphin-safe' label, complained to GATT. ${ }^{5}$ Mexico asked for a 
panel in February 1991, which reported back to the parties on 3 September 1991 with the following conclusions:

1. that the US could not embargo imports of tuna products from Mexico simply because Mexican regulations on the way tuna was produced did not satisfy US regulations.

2. that GATT rules did not allow one country to take trade action for the purpose of attempting to enforce its own domestic laws in another country - even to protect animal health or exhaustible natural resources. (WTO, 2016)

The panel was also asked to judge the US 'dolphin-safe' label, but concluded that 'it did not violate GATT rules because it was designed to prevent deceptive advertising practices on all tuna products, whether imported or domestically produced' (WTO, 2016). The case was settled 'out of court', with Mexico postponing further action.

As an immediate result, in 1992 the United States went along with a multilateral agenda for the catching of tuna in the ETP. In that context, the administration would 'look for a solution to this long-standing controversial matter, one which would reduce dolphin mortalities even faster and remove the trade sanctions' (US Department of State, 1992). GATT's findings provoked rage by many environmental groups, such as the EII and the Humane Society, that considered the GATT privileged trade at the expense of the environment. Concurrently, the US Department of State positioned itself in favor of foreign fleets - not just the Mexican - by highlighting their commitment to dolphin protection and by stating that it would not support 'any dolphin conservation bill that would install enhanced trade sanctions in US law that are so onerous as to create disincentives for international cooperation on this matter' (US Department of State, 1992). The concern with international cooperation comes to the fore in the Executive's position, as shown in the analytical framework, and mediates the environmental stance taken by the administration.

This section was intended to offer an account of the antecedents of the policy changes in the US 'dolphin-safe' label and to point out the preferences of the main policy actors involved in the issue. It showed that Congress was faced with an attentive public, while canners and fishermen were divided according to their dependency on the ETP region. In addition, this section showed that bureaucratic concerns lied beyond environmental protection and beyond the concern of impeding US tuna fleets to be at a competitive disadvantage. These elements were present, but the actions of the US bureaucracy were also related to the international implications of more stringent rules applied to foreign fleets. In addition, the GATT ruling made it clear that assertive measures might not be feasible due to possible retaliation and reputational costs coming from abroad. However, as presented in the next subsection, the position of the US Executive, in the frontier between domestic and international constraints, also gave it a strategic advantage to push for a given understanding of the 'dolphin-safe' standard. 


\subsection{Policy change in progress: multilateral compromises and domestic coalitions leading to the IDCPA (1992-1998)}

Even after the 1991 GATT consultations, US Congress was hesitant to leave aside its hardline stance on dolphin protection. The Executive, in turn, was looking for a more flexible approach to sanctions and tuna labeling in view of international constraints. To find a middle ground, in June 1992 the United States approved the International Dolphin Conservation Act (IDCA), which was also an attempt to settle the GATT case. The IDCA resulted from an agreement between the US, Mexico, and Venezuela and would (1) impose a five-year moratorium on the harvesting of tuna with purse-seine nets; and (2) lift tuna embargoes on those nations making a declared commitment to implement the moratorium and take further steps to reduce dolphin mortality (Inside US Trade, 1993). However, environmental groups were able to press Congress for stricter provisions (Inside US Trade, 1993). This led both Mexico and Venezuela to say afterwards that they would not implement the moratorium because the United States 'had substantially raised the economic stakes of the compromise' (Inside US Trade, 1993). As presented by the analytical framework, these events show that (1) the preferences of the Executive and Congress were not in alignment, and that (2) despite the unilateral elements present in the IDCA, foreign countries were willing to offer concessions to a certain limit in order to reach an agreement.

An element that served as an argument in favor of the more assertive position taken by Congress was the fact that NAFTA was being negotiated at the same time Mexico and the US tried to find a solution to the tuna-dolphin issue (Ferguson, 1993). Barbara Boxer (D-CA), for instance, stated that 'Mexico's challenge of [a] United States environmental law that protects dolphins doesn't speak well for its claim to be a full partner in the protection of the environment under the United States-Mexico trade agreement' (Musgrave and Stephens, 1993: 969). All things considered, the tuna-dolphin controversy was politically sensitive (Wright, 2000) and framed as a NAFTA issue by environmental groups, which relied upon its public salience to push for their objectives (Inside US Trade, 1993). In such a context, the United States had bargaining power vis-à-vis Mexico as the NAFTA negotiations were taking place and the Mexican government did not want to hurt its chances of getting a compromise approved by the US Congress (Bradsher, 1991).

On the other hand, the Department of State and the Department of Commerce were pushing the US Congress to accept that access to the US market might no longer be enough of a motive for developing countries to achieve further dolphin mortality reduction. According to the agencies, foreign countries considered that the US market was closed because of the embargoes and the 'dolphin-safe' label. As such, the administration advocated in favor of changing the tuna label and lifting embargoes, despite the willingness by Congress to keep such a label by means of approving DPCIA and despite the court decisions that ordered embargoes 
years before. As part of the administration's strategy, the La Jolla Agreement was finished in March 1992. This agreement did not focus on fishing methods - the object of Mexico's complaints - and instead on results (IATTC, 1997). Instead of a zero mortality goal, as advocated by the EII, the agreement aimed at an $80 \%$ reduction in dolphin mortality between 1993 and 1999. Both the IDCA and the La Jolla Agreement reflected the interests of the US Executive to mediate international trade and environmental protection to forge a win set between domestic and international constraints.

The countries that signed the La Jolla Agreement tried to press the US administration to take action by saying they would abandon the agreement in favor of a less restrictive multilateral arrangement (Wright, 2000). In turn, the US administration, willing to enter into an agreement, could make use of the threats made by the Mexican government to put pressure on Congress and 'get rid of an irritation' in the relationship between Mexico and US, as stated by an official (Inside US Trade, 1994). In other words, the US administration used foreign signals to convince a hesitant Congress. In that context, there were some bills showing up on the horizon, aiming at lifting US embargoes and changing the 'dolphin-safe' label. The tuna-dolphin issue became divided along partisan lines, with Republicans pushing for a more flexible standard and Democrats pushing for a hardline approach to dolphin protection, led by Barbara Boxer (D-CA) and other Democrats from California. In 22 August 1995, a legislation was formally introduced by Randy Cunningham (R-CA) who had the intention of lifting the US tuna embargoes and base US laws on the Inter-American Tropical Tuna Commission (IATTC), which would in practice mean a change in the US labeling system (Inside US Trade, 1995a). Another attempt to forge a win set between international and domestic pressures took place with the Panama Agreement, signed in October 1995. The agreement would allow tuna to be labeled 'dolphin-safe' even when encirclement techniques were used, as long as no dolphin was harmed in the process.

Along with the Panama Agreement, John Breaux (D-LA) and Ted Stevens (R-AL) introduced legislation to lift the US tuna embargo and change the 'dolphin-safe' definition, insofar as the other countries taking part in the agreement converted it into a binding commitment (Inside US Trade, 1995c). Congressional representatives also saw electoral advantages in promoting the return of the US fleet to the ETP, as it would 'bring new tuna processing jobs to California' (Eco-Safe Tuna, 2016). Outside the ETP, the US fleet had much more competition, and the smaller vessels just could not travel too far. For the administration, the support of the US fishermen was useful to give legitimacy to its efforts to build a winning coalition pro-policy change.

Some environmental groups such as Greenpeace, National Wildlife Federation, World Wildlife Fund (WWF), Environmental Defense Fund, and Center for Marine Conservation manifested themselves in favor of an international agreement (Woolf, 1997). This group had an ecosystemic approach to conservation and 
considered that the increased use of 'dolphin-safe' fishing methods would harm biodiversity by increasing the discard of juvenile tuna and the bycatch of nontarget species (Marine Mammal Commission, 1996: 103). They condemned, for instance, the use of Fish Aggregating Devices (FADs) - floating objects strategically placed to attract fish - which could involve the use of purse-seine nets, but not the encircling of dolphins. They differed from the EII to the extent that the latter had a specific focus on dolphin protection by reducing mortality to zero. Greenpeace's position on the bycatch of juvenile tuna was close to the one defended by the American Tunaboat Association when opposing the requirement of not setting nets on dolphins (Shabecoff, 1990) and, as such, shows that the division between environmental and industry concerns can be blurred at times. ${ }^{6}$

The support from Greenpeace and other NGOs could be used by the US Administration to persuade swing voters (Inside US Trade, 1995b). In addition to that, the US Executive was trying to make the point that foreign fleets had displayed their commitment to lower dolphin mortality as expressed in the considerably lower number of fatalities (Inside US Trade, 1995b). Also, in a letter to the Mexican government, Clinton asserted that getting the Panama Agreement ratified by the US Congress 'is a top priority for my Administration and for me personally' (Inside US Trade, 1996c). As such, Clinton was willing to assume a relevant role in pushing for an agreement. Once more, this shows the interest of the administration in promoting a compromise that would balance international constraints (WTO decisions, trade and diplomatic relations) and domestic demand for environmental protection.

The idea shared by the US administration, by US fishermen, and by Republicans was that the dolphin protection laws had served their purposes (Fiore, 1995). Specific environmental groups took part in that coalition as they believed in the need to shift the focus from a dolphin-protection approach to an ecosystemic one. With opponents of the existing 'dolphin-safe' label and embargoes gaining momentum, Barbara Boxer (D-CA) and Joseph Biden (D-DE) proposed an alternative to the Breaux-Stevens bill, ${ }^{7}$ keeping some important parts intact, particularly relative to the lift of embargoes, but dropping any changes in the 'dolphin-safe' label. A compromise between Republicans and Democrats was not that easy because Democrats, such as Gerring Studds (D-MA), insisted that no changes in the 'dolphin-safe' label should take place before a scientific study had been conducted to determine the long-term effects of encirclement and net-setting on dolphin reproduction and mortality (Inside US Trade, 1995a).

In that regard, the Boxer-Biden bill proposed two scientific studies, one on the problem of bycatch that might result from catching tuna using methods other

6 DeSombre (2000) calls this proximity between environmental and industry concerns 'Baptist-bootlegger' coalitions. This concept should be approached with care so as not to overestimate the proximity of interests. See Baird and Quastel (2011).

7 S.1420/HR.2823. 
than setting nets on dolphins and the other on the reproduction and mortality effects of using nets to encircle dolphins (Inside US Trade, 1996b). If, on the one hand, Republicans, the Clinton administration, and Greenpeace were in favor of an immediate change in the tuna label (Inside US Trade, 1996a), some Democrats stated that they would not go against a bill that would entertain the possibility of some sort of long-term 'stress' study. As such, in favor of a compromise, both Democrats and Republicans made specific concessions and entertained the possibility of a stress test on setting nets on dolphins, giving less attention to other fishing methods such as FADs, however. According to a senator, the concession offered by policy change supporters would require the administration to 'prove a negative', in other words, to show scientifically that encirclement did not have significant effects on dolphin populations (Inside US Trade, 1996a).

According to Table 1, scientific research conducted later on show that both purse-seine nets and FADs can in some way lead to bycatch of endangered specifies as well as to changes in the eating behavior of tuna. However, the absence of requirements for stress tests for FADs seemed to be associated with two main factors (1) with stress tests for alternative methods, supporters of a policy change would have to both prove that FADs were harmful and that encircling dolphins was not, giving more margin for contestation; (2) in spite of some early works (Hall, 1998) pointing out that FADs lead to thousands of times more bycatches than setting nets on dolphins, the idea of killing these mammals, in whatever amount, was hard to conceive at that moment.

In the end, the International Dolphin Conservation Program Act (IDCPA) of 1997 was approved with broad support from the House of Representatives (262-166) and, in 1998, the Agreement on the International Dolphin Conservation Program (AIDCP), which elevated the La Jolla Agreement to binding status, was signed by the US and Latin American countries. Only $8.52 \%$ of the Republicans who voted opposed the IDCPA, while $28.43 \%$ of the Democrats who voted supported it. On the Democrat side, those who voted in favor of the bill were close to the center of the ideological divide. Such moderate Democrats accounted for the bulk of the Democrat votes. They were mainly convinced by (1) the strong concessions offered; (2) the international pressures and their strategic use by the US Executive. Although it was not possible to note a considerable conservative-moderate divide in the Republican party, the IDCPA supports the idea that Republicans and moderate Democrats are more likely to vote in favor of trade bills. Mexican officials assured that their country would not object the legislation by using the argument that it violated the Panama Declaration (Inside US Trade, 1997a).

In sum, the process of policy change in the US 'dolphin-safe' standard counted on the sponsoring of the US Executive, supported by specific congressional and civil society allies. The GATT rulings favorable to Mexico and other foreign signals were used by the Executive to form a winning coalition of Republicans and 
Table 1. Selected recent studies on the effect of purse-seine nets and FADs

\begin{tabular}{|c|c|c|}
\hline Reference & Research question & Main finding \\
\hline \multicolumn{3}{|c|}{ Purse-seine nets with and without encircling of dolphins } \\
\hline Edwards (2007) & $\begin{array}{l}\text { Does fishery-related stress contribute to } \\
\text { the lack of recovery of dolphin } \\
\text { populations in the ETP? }\end{array}$ & $\begin{array}{l}\text { Negative impact of purse-seine methods on } \\
\text { dolphin reproduction }\end{array}$ \\
\hline Wade et al. (2007) & $\begin{array}{l}\text { Does fishery-related stress contribute to } \\
\text { the lack of recovery of dolphin } \\
\text { populations in the ETP? }\end{array}$ & $\begin{array}{l}\text { Negative impact of purse-seine methods on } \\
\text { dolphin reproduction }\end{array}$ \\
\hline $\begin{array}{l}\text { Amandè et al. } \\
\text { (2010) }\end{array}$ & $\begin{array}{l}\text { Do purse-seine nets generate consider- } \\
\text { able bycatch? }\end{array}$ & $\begin{array}{l}\text { Tuna purse-seining generates relatively } \\
\text { low levels of bycatch. Although, some } \\
\text { biologically sensitive species groups such } \\
\text { as sharks and turtles are impacted }\end{array}$ \\
\hline $\begin{array}{l}\text { Gerrodete et al. } \\
\text { (2012) }\end{array}$ & What methods lead to greater bycatch? & $\begin{array}{l}\text { Setting nets on dolphins does not cause as } \\
\text { much bycatch as fish aggregating devices, } \\
\text { which leads to two or three times more } \\
\text { bycatch than other methods }\end{array}$ \\
\hline \multicolumn{3}{|c|}{ Fish aggregating devices (FADs) } \\
\hline $\begin{array}{l}\text { Hallier and } \\
\text { Gaertner (2008) }\end{array}$ & $\begin{array}{l}\text { What, if any, are the detrimental effects } \\
\text { of FADs? }\end{array}$ & $\begin{array}{l}\text { FADs are a 'super-stimulus' and mislead } \\
\text { tunas towards inappropriate habitat } \\
\text { selection }\end{array}$ \\
\hline $\begin{array}{l}\text { Jaquemet, Poteir } \\
\text { and Ménard } \\
(2011)\end{array}$ & Do FADs impact eating habits of tuna? & $\begin{array}{l}\text { FADs contributed to changing eating } \\
\text { habits of tuna }\end{array}$ \\
\hline $\begin{array}{l}\text { Dagorn et al. } \\
\text { (2013) }\end{array}$ & What are the impacts of using FADs? & $\begin{array}{l}\text { Levels of non-tuna by-catch are compar- } \\
\text { able to or less than in other commercial } \\
\text { tuna fisheries and are primarily com- } \\
\text { prised of species that are not considered } \\
\text { threatened. }\end{array}$ \\
\hline Leroy et al. (2013) & $\begin{array}{l}\text { Do FADs increase the vulnerability of } \\
\text { marine species? }\end{array}$ & $\begin{array}{l}\text { Use of FADs has increased the vulnerabil- } \\
\text { ity of tuna and other fishes to the purse } \\
\text { seine method, including some shark and } \\
\text { billfish species }\end{array}$ \\
\hline
\end{tabular}

Source: Author.

moderate Democrats, corroborating the perspective that the US Executive can strategically use its position in the domestic-international frontier. The administration also counted on the support of the US tuna industry, which had been pushed away from the ETP. However, the legislation introducing the policy change had to contain concessions so as to accommodate opponents. These concessions came in the form of scientific studies and were necessary accommodate the liberal Democrats and reduce opposition from NGOs, such as the EII. Foreign partners, in turn - Mexico, particularly - tolerated the mixed signals coming from the US in view of their willingness to resolve the issue and access the US tuna market. 


\subsection{Policy change stalled: the use of courts by NGOs (1999-2004)}

In response to IDCPA's requirements, in April 1999 the NMFS found that it could not be concluded that encirclement as a method of fishing tuna caused significant adverse impact on depleted stocks of dolphins. This was the base of the administration's argument to change the 'dolphin-safe' label and was immediately followed by a lawsuit filed by the EII and the Humane Society on the basis of the American Procedures Act (APA). In the judicial review of the agency's ruling, the court found that 'the Secretary [of Commerce] failed ... to obtain even preliminary data from any of the Congressionally mandated stress research projects that would provide critical information regarding actual stress impacts in ETP depleted dolphin stocks'. ${ }^{8}$ When defending the finding made by the NMFS, the Department of Commerce affirmed that the 'Court should sustain the Secretary's action because Congress, in enacting IDCPA, chose to embrace and implement the Panama Declaration and thus change course from its previous approach to dolphin conservation'. 9 The court responded that the defendants 'overstated the matter', and affirmed that while Congress did embrace most of the Panama Agreement, particularly in terms of embargoes and trade restrictions - which resulted in the embargoes against Mexico being lifted in 12 April $2000-$ Congress made the changes in the 'dolphin-safe' label contingent upon scientific research.

When the Department of Commerce appealed, on 11 December 2000, the court rejected the arguments of the administration and responded:

In urging this court to reverse its decision, the defendants [state] that this case involves international concerns and competing policies for protecting dolphins. That it does, but it is not our role to make policy decisions about ETP dolphin conservation. Such decisions are within Congress' bailiwick, and both the Secretary and this court must defer to congressional intent as reflected in the IDCPA. ${ }^{10}$

The possibility of an unfavorable court ruling did not seem to have been anticipated by the Department of Commerce either because the administration considered that a non-conclusive finding would suffice as proof to fully implement the IDCPA or because it did not entertain the possibility of non-conclusive research findings.

The willingness of the US administration to push for a given way of approaching the tuna-dolphin issue can be further evidenced by the information available in a 2004 court decision. The document shows that the NOAA framework for making the final findings was considered 'not flexible' by the US Department of State. In September 2001, NOAA staff member Nicole LeBoeuf, explained that she would be updating her colleagues 'on a recent conversation I had with 
individuals from the Department of State, in which I gave them the [decision] framework diagrams for their review". In response, a staff member from the NOAA wrote to Ms. Le Boeuf stating that 'the message [she] was getting from Bill GF [from the Department of State] was one of considerable concern about the [Decision Analysis Framework]'. A new version of the framework would presumably leave more discretion to the Department of Commerce in making its final findings. ${ }^{11}$ These events took place concurrent with accusations made by two scientists of federally funded laboratories, charging their superiors of shutting down their research of level of stress in dolphins because it clashed with broader policy goals (Marquis, 2003a).

In 31 December 2002, the Department of Commerce of the Bush Administration made a final finding that encircling dolphins with nets to catch tuna did not cause significant harm. The EII filed a suit in the US District Court for the Northern District of California, claiming that the findings '[were] not supported by the research findings and other information and, therefore, that it was arbitrary and not in accordance with the applicable law' (Marine Mammal Commission, 2006). The EII affirmed having had access to NFMS research conducted from 1997 to 2002 that 'clearly shows that the technique favored by the Mexican fleet and other nations to catch tuna [setting nets on dolphins] harm dolphins' said David Phillips, director of the International Marine Mammal Protection (Palmer, 2003). In fact, four among the five independent experts hired by the government to review the integrity of the finding expressed concern about Commerce's rulings (Marquis, 2003b). The EII affirmed that the ruling went against the Department's own scientific finding and appeared to be a 'political gift' to Mexico (Marquis, 2003c). Instead of a 'political gift', however, it seems that the position of the US administration reflected its own approach as to the best mix between environmental protection and the maintenance of sound trade and diplomatic relations, as presented in the analytical framework.

In April 2003, the Ninth Circuit Court impeded the relaxation of the 'dolphinsafe' label, noting that 'Plaintiffs had nonetheless raised a serious question as to whether the Secretary's final finding was influenced by international trade policy considerations, thus compromising the integrity of the decision-making process'. ${ }^{12}$ In August 2004, based on lack of evidence to 'prove a negative' - as feared by some representatives in the process of getting the IDCPA approved the court ordered that the 'dolphin-safe' label should not be relaxed. In the decision, the court found that the 'record reflects an agency that gave short shrift to the conclusions of its own scientists, dragged its feet on crucial research, and essentially ignored the explicit warning of the appellate court not to invoke 
'insufficient evidence' as a justification for its finding', and stated that the Court had no choice but to conclude that the final finding was based on 'factors which Congress has not intended [the agency] to consider'. In the decision, the court added a section called 'integrity of decision-making', in which it argued that there were 'plentiful circumstantial evidence' that the final finding was motivated by trade policy considerations and not by science and that the Department of State and Mexico were strongly pushing for a 'No Significant Adverse Impact'. ${ }^{13}$ The US administration appealed and, once more, in April 2007, the Ninth Circuit Court of Appeals ruled against it.

In sum, the need to 'prove a negative' was part of a deliberate strategy of the administration, a necessary concession to assure a winning coalition favorable of a policy change. The concessions that the pro-policy change coalition had to make to find a common ground between domestic and international preferences resulted in the IDPCA policy change being partially reversed after the judicial review conducted by the Ninth Circuit Court of Appeals, considered the EII's 'ally in the judiciary' (Bonanno and Constance, 2010: 81). The lack of scientific information, along with the jurisprudence created by the judicial review of each of the two NFMS findings, strengthened the 'dolphin-safe' standard against further legal questioning, locking-in the existing label against new policy change attempts, as I will show below. This outcome was reinforced by the evidence that the population of dolphins in the ETP region was not recovering - although more recently a NOAA report showed signs of an initial recovery (Gerrodette et al., 2008). Neither the findings that led to the judicial review, nor the blocking power of the judicial review itself were anticipated by the US Executive, reinforcing the idea that, in addition to being a political victory of the EII and its allies, the lockin of the existing standard was an unintended consequence of the concessions offered to change the 'dolphin-safe' label in the first place.

\subsection{Readjusting to the new WTO findings (2005-2017)}

The reversal of the policy change described above limited new legislative attempts to relax the US 'dolphin-safe' standard. An investigation of the bills that were introduced since the Truth in Tuna Labeling Act of 2003 shows few bills with tunadolphin issues in their scope and none of them proposed a change in the 'dolphin-safe' label - see Table 2. Wayne Gilchrest (R-MD), who exercised considerable leadership in the Republican party on issues related to environmental protection tried on some occasions to change the definition of the ETP and reduce its limits, but did not refer to the 'dolphin-safe' label. Differently, since 2008, the tuna-dolphin issue was present in bills that sought to improve the enforcement of the existing 'dolphin-safe' standard. 
Table 2. Bills with tuna-dolphin issues in their scope (2004-2016)

\begin{tabular}{|c|c|c|c|}
\hline $\begin{array}{l}\text { Reference/ } \\
\text { enacted? }\end{array}$ & $\begin{array}{l}\text { Year of introduction } \\
\text { (reintroduced?) }\end{array}$ & Name & Scope of tuna-dolphin provisions \\
\hline $\begin{array}{l}\text { H.R. } 774 \\
\text { Yes }\end{array}$ & $\begin{array}{l}2009(2011,2012 \\
2013,2015)\end{array}$ & $\begin{array}{l}\text { Illegal, Unreported, and } \\
\text { Unregulated Fishing } \\
\text { Enforcement Act of } 2015\end{array}$ & $\begin{array}{l}\text { Strengthens enforcement mechan- } \\
\text { isms to stop illegal, unreported, and } \\
\text { unregulated fishing by amending } \\
\text { DCPIA }\end{array}$ \\
\hline $\begin{array}{l}\text { S. } 52 \\
\text { No }\end{array}$ & $2008(2011,2013)$ & $\begin{array}{l}\text { International Fisheries } \\
\text { Stewardship and } \\
\text { Enforcement Act }\end{array}$ & $\begin{array}{l}\text { Establishes uniform administrative } \\
\text { and enforcement procedures and } \\
\text { penalties for enforcement of } \\
\text { specific statutes, including DCPIA }\end{array}$ \\
\hline $\begin{array}{l}\text { H.R. } 2130 \\
\text { No }\end{array}$ & 2005 & $\begin{array}{l}\text { Marine Mammal } \\
\text { Protection Act } \\
\text { Amendments }\end{array}$ & $\begin{array}{l}\text { Changes the definition of ETP, } \\
\text { reducing its limits from } 160 \text { degrees } \\
\text { west longitude to } 150 \text { degrees west } \\
\text { longitude }\end{array}$ \\
\hline $\begin{array}{l}\text { H.R. } 5104 \\
\text { No }\end{array}$ & 2004 & $\begin{array}{l}\text { Prescott Marine Mammal } \\
\text { Stranding Program } \\
\text { Amendments of } 2004\end{array}$ & $\begin{array}{l}\text { Changes the definition of ETP, } \\
\text { reducing its limits from } 160 \text { degrees } \\
\text { west longitude to } 150 \text { degrees west } \\
\text { longitude }\end{array}$ \\
\hline $\begin{array}{l}\text { H.R. } 2693 \\
\text { No }\end{array}$ & 2004 & $\begin{array}{l}\text { Marine Mammal } \\
\text { Protection Act } \\
\text { Amendments of } 2004\end{array}$ & $\begin{array}{l}\text { Changes the definition of ETP, } \\
\text { reducing its limits from } 160 \text { degrees } \\
\text { west longitude to } 150 \text { degrees west } \\
\text { longitude }\end{array}$ \\
\hline
\end{tabular}

Source: Author with data from Govtrack.us.

Noting the difficulty in changing the 'dolphin-safe' label in the US Congress, in 2008 Mexico brought a new complaint to the WTO's Dispute Settlement Body ${ }^{14}$ and challenged the US 'dolphin-safe' label as not being consistent with Articles I:1 and III:4 of the GATT 1994 and Article 2.1, 2.2, and 2.4 of the Agreement on Technical Barriers to Trade (TBT). In May 2011, a confidential interim report circulated by the WTO found that the US 'dolphin-safe' label violated article 2.2 of TBT, which forbids WTO members from implementing 'technical regulations' that are 'more trade restrictive than necessary to fulfill a legitimate purpose'. However, Mexico's victory was limited as the panel did not find that the US regulations violated articles 2.1 and 2.4 of $\mathrm{TBT}^{15}$ as argued by the Latin

14 United States-Measures Concerning the Importation, Marketing and Sale of Tuna and Tuna Products, Dispute DS381.

15 Under Article 2.1, members must guarantee that imported products are 'accorded treatment no less favorable than that accorded to like products of national origin and to like products originating in any other country". Article 2.4 states that where technical regulations are required and "relevant international standards exist", WTO members shall use them as a basis for their technical regulations "except when such international standards ... would be an ineffective or inappropriate means for the fulfillment of the legitimate objectives pursued (WTO, 2017). 
American country. The objectives behind the 'dolphin-safe' label were found to be legitimate according to WTO rules, but were considered more trade restrictive than necessary. In rejecting Mexico's claim that the US was in violation of article 2.4 of TBT, the panel found that the US was allowed to 'go beyond' international standards as long as the difference in condition was proportional to the difference in treatment (Inside US Trade, 2011).

In January 2012, the US appealed, arguing that the label requirements were not technical regulations, which the TBT agreement considers as measures 'with which compliance is necessary', and instead called them non-mandatory standards. The United States also considered that the panel finding was incorrect in the analysis of the relative harm of setting nets on dolphins outside the ETP, given that dolphins do not usually associate with tuna in other areas. It defended that the AIDCP scheme was not sufficient as an alternative to the 'dolphin-safe' label (Inside US Trade, 2012b). Mexican trade officials considered that a change in the label would require the MMPA to be modified, and United States Trade Representative (USTR) officials said the administration could not compromise in favor of such a change domestically (Inside US Trade, 2012a).

In June 2012, the WTO Dispute Settlement Body found that the US 'dolphinsafe' label was inconsistent with Article 2.1 of the Agreement on Technical Barriers to Trade (WTO, 2016). In response to that finding, on 9 July 2013, the NMFS published a rule - 'Enhanced Document Requirements to Support Use of the Dolphin Safe Label on Tuna Products' - that modified the labeling conditions to fully address the risks posed by tuna fishing outside the ETP (Federal Register, 2016). Specifically, the final rule amended the eligibility criteria for tuna products to be labeled 'dolphin-safe', expanding the existing standard to all fisheries, instead of just the ETP (Federal Register, 2016). The NMFS rulings were applauded by the Humane Society, the EII, and others. In view of the lock-in of the 'dolphin-safe' standard at home, the US government opted for a highest common denominator approach vis-à-vis the WTO's rulings. Both the abrupt reduction in the number of bills presented to the US Congress and the new position of the US Executive show a consistent, experience-driven change in the beliefs regarding the prospects of new policy changes in the direction initially desired by Republicans, tuna boat owners and the Executive itself.

In supporting an expansion of the label, the US Executive went both against canneries and US fishermen, concerned about the greater costs associated with the regulations, and NGOs, such as Greenpeace, which had an approach to dolphin protection that was different from the EII's. Tri-Marine, StarKist, and Bumble Bee, American Tunaboat Association (ATA), and the National Fisheries Institute (NFI) expressed objection to the rule: 'We believe the proposed modification of the Dolphin Safe program expands the program's scope unnecessarily and weakens its impact in the process. The proposed rule will not drive change in behavior, only change in the amount of paperwork' (Stelle Jr., 2013: 1). Opposing NGOs said that 'NOAA ... perpetuated the failings of the 
current 'dolphin-safe' labeling regime' (Eco-safe Tuna, 2016). For the US tuna boats operating in Pago Pago and American Samoa in response to ETP's regulations, the expansion of the requirements would put them in competitive disadvantage $v i s$-à-vis other fish and non-fish products, the same applying for tuna canners.

Despite the rulings, Mexico considered that the US did not comply with the WTO, given that, within the ETP, tuna caught with purse-seine nets was required to be accompanied by a certification from both the ship captain and from an independent observer. This was not a requirement in other fisheries. Also, Mexico considered that there still was discrimination related to methods of fishing tuna. While vessels using any gear for catching tuna had to certify that no dolphin was killed or seriously injured, those using purse seine nets also had to certify that no dolphin was 'intentionally encircled' (Inside US Trade, 2013). The WTO established a compliance panel on 27 January 2014 and its final report (April 2014) found that the amended 'dolphin safe' labeling still discriminated against Mexico (Federal Register, 2016). However, the panel accepted that there was evidence that encircling dolphins is particularly harmful to those animals and thus considered that US was justified in not allowing tuna caught by setting nets on dolphins to be labeled 'dolphin-safe'. The US said it was satisfied with the 'mixed ruling' (Inside US Trade, 2015a).

In view of the WTO findings, the Obama administration decided to go even further in the expansion of the scope of US 'dolphin-safe' standards, and on 23 March 2016 posted the ruling 'Enhanced Document Requirements and Captain Training Requirements to Support Use of the Dolphin Safe Label on Tuna Products' for public comments. Main changes in relation to the 2013 ruling are: (1) captains of those ships operating outside the ETP had to certify that no purse seine net or other fishing gear was intentionally deployed on or used to encircle dolphins, and that no dolphins were killed or seriously injured when gear was deployed to catch tuna; and (2) the new rule allows the NMFS assistant administrator to require an on-board observer to certify the tuna caught outside the ETP meets the 'dolphin safe' labeling requirements, in the event the NMFS assistant administrator determines that a fishery presents a regular and significant association between dolphins and tuna and/or has a regular and significant track of dolphin mortality or serious injury (Inside US Trade, 2016a). This new expansion in scope once more indicates the need for a highest common denominator approach in regard to the WTO's decision given the difficulties of changing the 'dolphin-safe' label at home.

In April 2016, the US requested the establishment of a compliance panel, and in May 2016 Mexico also announced a request to establish its own compliance panel (Inside US Trade, 2016b). In April 2017, the Arbitrator circulated its decision and determined that the impairment suffered by Mexico as a result of the 2013 Tuna Measure is US\$163.23 million per year. In 22 May, Mexico was granted the right to retaliate against the United States. Note, however, that the decision is 
relative to the 2013 rule created by the US, not to the most recent one, on which a decision has not yet been circulated. In case the new decision finds that the 2016 NMFS rule is compliant with WTO rules, Mexico will have to stop its retaliation against the US.

In sum, the locking-in of the US 'dolphin-safe' label both restricted legislative activity in favor of a more flexible standard and forced the US Administration to take a distinct approach in dealing with the subject vis-à-vis domestic allies, the WTO, and foreign countries. A complementary explanation to the greatest common denominator approach to the tuna-dolphin issue in the Obama administration could be that the president was concerned about pleasing environmental groups so as to soften their opposition towards the Transpacific Partnership (TPP). However, it does not explain why the administration did not take a similar approach when dealing with the Country of Origin Labeling (COOL) for beef and pork (Inside US Trade, 2015b) after a long dispute with Canada. As such, this alternative does not seem to be the main motive why the administration acted as it did.

\section{Conclusion}

This paper addressed three main questions: 'why did a policy change in the US' tuna-dolphin standard take place?'; 'why was it partially reversed?'; and 'what were the consequences of this partial reversal?'. The process tracing used to answer these questions found that the US Executive pushed for its own perspective on how to solve the tuna-dolphin issue. The administration built a coalition with actors with similar preferences in Congress and in the civil society (Republicans and tuna boat owners). However, the concessions that groups in favor of a policy change had to make to approve the modification in the US 'dolphin-safe' standard laid the ground for the partial reversal of such a policy change, as well as its lock-in. This result - an unintended consequence of the ICDPA's approval - provided policymakers with the experience-based learning that both reduced legislative action and resulted in the US government changing its initial position vis-à-vis its domestic allies and international partners. This is evidenced by the recent WTO dispute between Mexico and the US, in which the latter sought a highest common denominator by expanding the US 'dolphin-safe' label to areas other than the ETP.

The changes in the US position may be evidence of the stability of a 'dolphinsafe' label centered on zero dolphin mortality. The situation can change if the NOAA finds very strong evidence that the population of dolphins in the ETP is recovering - indeed, an NOAA report shows an initial recovery (Gerrodette et al., 2008); however, this is not enough to create a new movement towards relaxing the 'dolphin-safe' label. Supporters of a lenient 'dolphin-safe' standard would also build up momentum if the WTO panel finds that the 2016 NFMS rule does not comply with trade rules, particularly in the context of the Trump administration. 
The analysis carried out in the pages above offers distinct contributions to the literature. First, by studying the US decision-making process, this paper shows how an eco-label, as a transmission belt of consumers' ethical concerns, can impact trade politics. In that regard, although protection of US fishermen from environmental dumping and competitiveness disadvantage was a concern for the US Congress, it would be hard to state it was the main, let alone the only motivation behind the US 'dolphin-safe' standard. The idea of a lock-in of the 'dolphin-safe' label also contributes to nuance the affirmation that the WTO's rulings are always detrimental to the environment. Recent WTO findings that considered the label a legitimate concern, however, put in question its exclusive use in the ETP. The response of the US administration to the ruling was, in turn, applauded by NGOs such as the EII itself. In that case, when sustainability standards at home are hard to change, there may be an increase in the level of environmental protection $^{16}$ in face of the WTO's decisions, since modifications must be done at a highest common denominator so as not to be discriminatory. The article also presents new ways on how policy changes can be stalled. The literature on veto points (Tsebelis, 2002) does not usually consider courts judging procedural control as veto players, but the tuna-dolphin case offers an exception, as judicial review of the bureaucracy acted as a veto point.

In addition, the paper brings forth the view of jurisprudence as an element potentially supporting the institutionalization of standards and, from the perspective of the two-level games, it shows how it is possible to account for US' involuntary defection vis-à-vis its international commitments, even after ratification. Finally the research presents ways in which norms are propagated from the US to other regions of the world, not as part of a deliberate strategy but as a result of domestic and international constraints that may lead to unintended consequences. Each of the elements above deserves to be further investigated through future works.

\section{References}

Amandé, M., J. Ariz, E. Chassot, A. Molina, D. Gaertner, H. Murta, R. Pianet, J. Ruiz, and P. Chavance (2010), 'Bycatch of the European Purse Seine Tuna Fishery in the Atlantic Ocean for the 2003-2007 Period', Aquatic Living Creatures, 23: 353-362.

Baird, I. and N. Quastel (2011), 'Dolphin-Safe Tuna from California to Thailand: Localisms in Environmental Certification of Global Commodity Networks', Annals of the Association of American Geographers, 101(2): 337-355.

Bennett, A. and A. George (1997), 'Process Tracing in Case Study Research', Paper prepared to the MacArthur Foundation Workshop on Case Study Methods, 17-19 October.

Bonanno, A. and D. Constance (2010), Stories of Globalization: Transnational Corporations, Resistance and the State, University Park, PA: The Pennsylvania State University Press.

Bradsher, K. (1991), 'Official Tells of Progress on Trade', New York Times, 25 November: D.2.

16 This is contingent upon the idea of conservation held by distinct groups, as the fissure between the EII and Greenpeace attests. 
Burney, D. (1988), 'Statement on Behalf of the US Tuna Foundation: In US Senate, Committee on Commerce, Science, and Transportation, the Reauthorization of the Marine Mammal Protection Act', Government Printing Office, Washington, DC, pp. 130-137.

Conceição-Heldt, E. (2013), 'Two-Level Games and Trade Cooperation: What Do We Now Know?', International Politics, 50(4): 579-599.

Crowley, M. and R. Howse (2014), 'Tuna-Dolphin II: A Legal and Economic Analysis of the Appellate Body Report', World Trade Review, 13(2): 321-355.

Cullet, P. and A. P. Kameri-Mbote (1996), 'Dolphin Bycatches in Tuna Fisheries: A Smokescreen Hiding the Real Issues?', Ocean Development and International Law, 27: 333-348

Curtin, P. and S. Eastman (1989), 'Beach City Urges Residents to Stop Eating Tuna', St. Petersburg Times, 7 July.

Dagorn, L., K. Holland, V. Restrepo, and G. Moreno (2013), 'Is It Good or Bad to Fish with FADs? What Are the Real Impacts of the Use of Drifting FADs on Pelagic Marine Ecosystems?', Fish and Fisheries, 14(3): 391-415.

De Sombre, E. (2000), Domestic Sources of International Environmental Policy: Industry, Environmentalists and US Power, Cambridge, MA: MIT Press.

De Vos, B. and S. Bush (2011), 'Far More than Market-Based: Rethinking the Impact of the Dutch Viswijzer (Good Fish Guide) on Fisheries' Governance', Sociologia Ruralis, 51(3): 284-303.

Destler, I. M. (2005), American Trade Politics, 4th edn, Washington, DC: Institute for International Economics.

Destler, I. M. and P. Balint. (1999), The New Politics of American Trade, Washington, DC: Peterson Institute of International Economics.

Eco-safe Tuna (2016), NOAA Says 'No' to Dolphin-Safe, www.ecosafetuna.org/press-room/announcements/noaa-says-dolphin-safe.html (accessed 30 March 2016).

Edwards, E. (2007), 'Fishery Effects on Dolphins Targeted by Tuna Purse-seiners in the Eastern Tropical Pacific Ocean', International Journal of Comparative Psychology, 20(2): 217-227.

Epstein, D. and S. O'Halloran (1996), 'Divided Government and the Design of Administrative Procedures: A Formal Model and Empirical Test', Journal of Politics, 58(2): 373-397.

Federal Register (2016), Enhanced Document Requirements and Captain Training Requirements to Support Use of the Dolphin Safe Label on Tuna Products, www.federalregister.gov/articles/2016/ 03/23/2016-06450/enhanced-document-requirements-and-captain-training-requirements-to-suppo rt-use-of-the-dolphin-safe (accessed 9 May 2016).

Ferguson, T. (1993), 'Business World: One Entangling Edible in the GATT Fight', Wall Street Journal, 26 November.

Fiore, F. (1995), 'Activists Alarmed by Bid to Reverse Dolphin-Safety Law: Ocean: GOP Bill Would Lift Ban on Tuna Caught when the Mammals Are Killed. Free-Trade Treaties Muddy Waters', Los Angeles Times, 9 September, http://articles.latimes.com/1995-09-09/news/mn-44002_1_dolphin$\mathrm{kill} / 2$.

Fioretos, O. (2011), 'Historical Institutionalism in International Relations', International Organization, 65(2): 367-399.

Gerrodette, T., G. Watters, W. Perryman, and L. Ballance (2008), 'Estimates of 2006 Dolphin Abundance in the Eastern Tropical Pacific, with Revised Estimates from 1986-2003', NOAA Technicical Memorandum NMFS, April.

Gerrodette, T., R. Olson, S. Reilly, G. Waters, and W. Perrin (2012), 'Ecological Metrics of Biomass Removed by Three Methods of Purse-Seine Fishing for Tunas in the Eastern Tropical Pacific Ocean', Conservation Biology, 26(2): 248-256.

Goldstein, J. (1986), 'The Political Economy of Trade: Institutions of Protection', American Political Science Review, 80(1): 161-84.

Giovannucci, D. and S. Ponte (2005), 'Standards as New Forms of Social Contract? Sustainability Initiatives in the Coffee Industry', Food Policy, 30: 284-301.

Hale, J. (1995), 'The Making of the New Democrats', Political Science Quarterly, 110(5): 207-232.

Hall, M. (1998), 'An Ecological View of the Tuna-Dolphin Problem: Impacts and Trade-Offs', Reviews in Fish Biology and Fisheries, 8: 1-34. 
Hallier, J. and D. Gaertner (2008), 'Drifting Fish Aggregation Devices Could Act as an Ecological Trap for Tropical Tuna Species', Marine Ecology Progress Series, 353(3): 255-264.

Humphries, M. A. and D. Songer. (1999), 'Law and Politics in Judicial Oversight of Federal Administrative Agencies', Journal of Politics, 61(1): 208-210.

Hutchings, V. (2001), 'Political Context, Issue Salience, and Selective Attentiveness: Constituent Knowledge of the Clarence Thomas Confirmation Vote', Journal of Politics, 63(3): 846-868.

IATTC - Inter-American Tropical Tuna Commission (1997), Minutes of the 59th Meeting, www.iattc.org/ Minutes/Archives/Minutes-IATTC-59-Oct-97ENG.pdf (accessed 23 April 2016).

Iida, K. (1993), 'When and How Do Domestic Constraints Matter? Two-Level Games with Uncertainty', Journal of Conflict Resolution, 37(3): 403-426.

Inside US Trade (1993), 'Environmental Groups Press for Dolphin Mortality Ban as Condition for NAFTA', 30 April.

_ (1994), 'US Considers Changing Tuna-Dolphin Law at Mexican Urging', 1 July. (1995a), 'California Republicans Introduce Bill to Lift Tuna Embargo', 22 June. (1995b), 'Latin Nations Propose More Dolphin Protection to End Tuna Fight', 4 October. - (1995c), 'Senators Ready Dolphin Bill after Talks with Tuna, Green Groups', 17 November. (1996a), 'Hollings Makes Last Ditch Effort to Broker Tuna-Dolphin Compromise', 12 July. (1996b), 'Boxer, Biden Submit Tuna-Dolphin Bill to Compete with Breaux-Stevens', 8 December 1995.

(1996c), 'Clinton Pledges Early, Renewed Effort to Pass Tuna-Dolphin Bill', 18 October.

_ (1997), 'Tuna-Dolphin Law Delays Label Change until Commerce Study is Done', 8 August. (2011), 'Mexico Prevails in Tuna Fight but Extent of Victory is Limited', 20 May.

(2012a), 'Mexico Confident US Will Comply with Tuna Ruling to Provide Market Access', 25 May. (2012b), 'US, Mexico Launch Separate WTO Appeals in US Tuna Labeling Case', 27 January. - (2013), 'Mexico Says Draft US Tuna Labeling Rule Does Not Remove Discrimination', 3 May. (2015a), 'WTO Finds US Tuna Labeling Rules Still Discriminate Against Mexico', 17 April.

(2015b), 'USTR Says Voluntary Cool Label Ok, but Retaliation Looms Over Debate', 6 August. (2016a), 'US Claims Compliance in WTO Tuna Dispute with Second Modified Rule', 25 March.

_ (2016b), 'US, Mexico Brawl Over Arbitration, Compliance Procedures in Tuna Fight', 29 April.

Jaquemet, S., M. Potier, and F. Ménard (2011), 'Do Drifting and Anchored Fish Aggregating Devices (FADs) Similarly Influence Tuna Feeding Habits? A Case Study from the Western Indian Ocean', Fish Resources, 107: 283-290

Johnson, E. and A. Prakash (2007), 'NGO Research Program: A Collective Action Perspective', Policy Science, 403: 221-240.

Joseph, J. (1994), 'The Tuna-Dolphin Controversy in the Eastern Pacific Ocean: Biological, Economic, and Political Impacts', Ocean Development and International Law, 25:1-30.

Karol, D. (2000), 'Divided Government and US Trade Policy: Much Ado about Nothing?', International Organization, 54(4): 825-844.

Korber, A. (1998), 'Why Everybody Loves Flipper: The Political-Economy of the US Dolphin-Safe Laws', European Journal of Political Economy, 14: 475-509.

Leroy, B., J. Phillips, S. Nicol, G. Pilling, S. Harley, D. Bromhead, S. Hoyle, S. Caillot, V. Allain, and J. Hampton (2013), 'A Critique of the Ecosystem Impacts of Drifting and Anchored Fads Use by Purse-Seine Tuna Fisheries in the Western and Central Pacific Ocean', Aquatic Living Creatures, 26(4): 49-61.

Marine Mammal Commission (1996), Annual Report to the Congress, www.mmc.gov/letters-and-reports/ reports/annual-reports/ (accessed 23 March 2016).

- (2006), Annual Report to the Congress, www.mmc.gov/letters-and-reports/reports/annual-reports/ (accessed 23 March 2016).

Marquis, C. (2003a), '2 Scientists Contend US Suppressed Dolphin Studies', New York Times, 9 January 2003, A.24.

(2003b), 'Rule Weakening Definition of "Dolphin Safe" is Delayed', New York Times, 10 January. (2003c), 'US Rules that Foreign Fleets' Use of Tuna Nets Is Safe for Dolphins', New York Times, 1 January. 
May, P. (1992), 'Policy Learning and Failure', Journal of Public Policy, 12(4): 331-354.

McCubbins, M., R. Noll, and B. Weingast (1987), 'Administrative Procedures as Instruments of Political Control', Journal of Law, Economics and Organization, 3(2): 243-277.

Meinert, D. (1989), 'Tuna Officials, US Oppose Can-Labeling Info', The Tribune, 5 October, A.18.

Mo, J. (1994), 'The Logic of Two-Level Games with Endogenous Domestic Coalitions', Journal of Conflict Resolution, 38(3): 402-422.

Musgrave, K. and G. Stephens (1993), 'The GATT-Tuna Dolphin Dispute: An Update’, Natural Resources Journal, 33: 957-975.

National Oceanic and Atmospheric Administration (NOAA) (2017), Text of the Marine Mammal Protection Act, http://www.nmfs.noaa.gov/pr/laws/mmpa/text.htm (accessed 19 August 2017).

New York Times (1989), 'US Defends Law on Monitoring Dolphin Killings', 23 August, A.14.

Olson, M. (1977), The Logic of Collective Action: Public Goods and the Theory of Groups, Cambridge, MA: Harvard University Press.

Palmer, M. (2003), 'Secret dolphin report released', Earth Island Journal, 18(1): 17-18.

Putnam, R. (1988), 'Diplomacy and Domestic Politics: The Logic of Two-Level Games', International Organization, 42(3): 427-460.

Rainforest-Alliance (2012), Towards Sustainability: The Roles and Limitations of Certification, June.

Rasmussen, A., B. Carroll, and D. Lowery (2014), 'Representatives of the Public? Public Opinion and Interest Groups Activity', European Journal of Political Research, 53(2): 250-268.

Sabatier, P. and C. Weible (2007), 'The Advocacy Coalition Framework - Innovations and Clarifications', in Paul A. Sabatier (ed.), Theories of Policy Process, Boulder, CO: Westview Press, pp. 189-223

Shabecoff, P. (1988), 'Senate Panel Urged to Toughen Curbs on Killing of Dolphins', New York Times, 14 April.

_ (1990), ‘3 Companies to Stop Selling Tuna Netted with Dolphins', New York Times, 13 April, A.1.

Sheehan, R. (1990), 'Administrative Agencies and the Court: A Reexamination of the Impact of Agency Type on Decisional Outcomes', Western Political Quarterly, 43: 875-885.

Stelle, W., Jr. (2013), 'Enhanced Document Requirements and Captain Training Requirements to Support Use of the Dolphin Safe Label on Tuna Products, Interim Final Rule', NOAA-NMFS-2016-0012, 81 Fed. Reg. 15444, Public Comment from the National Fisheries Institute to the US Federal Register.

Sustein, C., D. Schkade, L. Ellman, and A. Sawicki (2006), Are Judges Political? Washington, DC: Brookings Institution.

Teisl, M., B. Roe, and R. Ricks (2002), 'Can Eco-Labels Tune a Market? Evidence from Dolphin-Safe Labeling', Journal of Environmental Economics and Management, 43(3): 339-359.

Tsebelis, G. (2002), Veto Players: How Political Institutions Work, Princeton, NJ: Princeton University Press.

United Nations General Assembly - UNGA (1989), 'Large-Scale Pelagic Driftnet Fishing and Its Impact on the Living Marine Resources of the World's Oceans and Seas', A/RES/44/225.

US Department of State (1992), 'US Policy on Tuna-Dolphin Issues', US Department of State Dispatch 3 (34): 667, 24 August.

Vandergeest, P. and A. Unno (2012), 'A New Territoriality? Aquaculture Certification, Sovereignty, and Empire', Political Geography, 31: 358-367.

Vandergeest, P., S. Ponte, and S. Bush (2015), 'Assembling Sustainable Territories: Space, Subjects, Objects, and Expertise in Seafood Certification', Environment and Planning, 47: 1-19.

Volcansek, M. (2001), 'Constitutional Courts as Veto Players: Divorce and Decrees in Italy', European Journal of Political Research, 39(3): 347-372

Wade, P., G. Watters, T. Gerrodette, and S. Reilly (2007), 'Depletion of Spotted and Spinner Dolphins in the Eastern Tropical Pacific: Modeling Hypotheses for Their Lack of Recovery', Marine Ecology Progress Series, 343: 1-14.

Weisskopf, M. (1988), 'Tuna-Fishing Casualties: Dolphins, Thousands Killed, Senators Told', The Washington Post, 14 April.

Woolf, N. (1997), Greenpeace, Other Groups Praise New US Congressional Effort, www.naiaonline.org/ articles/article/greenpeace-other-groups-praise-new-us-congressional-effort (accessed 1 April). 
Wright, B. (2000), 'Environmental NGOs and the Dolphin-Tuna Case', Environmental Politics 9(4): 83-103.

World Trade Organization (WTO) (2016), Environmental Disputes, www.wto.org/english/tratop_e/ envir_e/edis04_e.htm (accessed 4 May 2017).

- (2017), 'TBT Agreement', https://www.wto.org/english/docs_e/legal_e/17-tbt_e.htm (accessed 20 August). 